\title{
A Review on Existing Tetracyclines Analogues and Their Pharmacologically Targeted SAR
}

\author{
Samreen Tanveer ${ }^{1, *}$, Athar Masood ${ }^{2}, K_{\text {Kanwal Ashiq }}^{3}$, Mehwish Qayyum ${ }^{3}$, Mayyda Asif Bajwa ${ }^{3}$, Asma Shah \\ Rukh $^{4}$, Afshan Arshad ${ }^{5}$, Raeesa Sattar ${ }^{5}$ \\ ${ }^{1}$ Faculty of Pharmacy, University of Central Punjab Lahore, Pakistan. \\ ${ }^{2}$ Riphah Institute of Pharmaceutical Sciences, Riphah International University, Lahore. \\ ${ }^{3}$ Faculty of Pharmaceutical Sciences, Superior College 17-km Raiwind Road Lahore, Pakistan. \\ ${ }^{4}$ University of Punjab, Pakistan. \\ ${ }^{5}$ Department of Allied Health Sciences, Superior College 17-km Raiwind Road Lahore, Pakistan.
}

\begin{abstract}
Authors' Contributions
1 Conception \& Study design, Data Collection

\& Processing, Data Analysis and /or interpretation, Drafting of Manuscript, Critical Review.

2 Data Collection \& Processing, Drafting of Manuscript, Critical Review.

3 Data Analysis and /or interpretation, Critical Review.

4 Conception \& Study design, Data Collection $\&$ Processing.

5 Data Analysis and /or interpretation, Critical Review.

6 Data Collection \& Processing, Data Analysis and /or interpretation.

7 Data Collection \& Processing, Critical Review.

8 Data Analysis and /or interpretation.

Acknowledgement

The authors are thankful to University of Central Punjab, Superior College Lahore and Riphah Institute of Pharmaceutical Sciences and Punjab University, Pakistan for providing literature review facility to carry out the work.

Article info.

Received: August 18, 2020

Accepted: January 13, 2021

Funding Source: Nil

Conflict of Interest: Nil

Cite this article: Tanveer S, Masood A, Ashiq K, Qayyum M, Bajwa MA, Rukh AS, Arshad A, Sattar R. A Review on Existing Tetracyclines Analogues and Their Pharmacologically Targeted SAR. RADS J Pharm Pharm Sci. 2020; 8(3):173-180.
\end{abstract}

*Address of Correspondence Author: Samreen_tanveer@yahoo.com

\section{A B S T R A C T}

Background: Tetracyclines belong to a class of broad spectrum antibiotics. Around the globe, they are prescribed to treat various gram negative and gram positive bacterial infections. Once in the cell, they reversibly bind to the receptors which are located on $30 \mathrm{~S}$ subunit of bacterial ribosome. They act by averting the protein synthesis, in turn, halting the bacterial growth.

Aim and Objectives: The aim of current review is to study tetracyclines, identifying potential activity against infections and highlighting the microbial resistance associated with various analogues.

Material and Method: The data for this review is collected from various databases including Scopus, PubMed, Springer Link and Google Scholar. To ensure the credibility only indexed articles were used in current study.

Result: The outcome of the study has suggested that tetracyclines and number of its analogues show selective bioactivity and strength to the biological targets. Through modification at certain positions, activity of drug is changed substantially. This not only affects therapeutic activity and safety profile but also has influence the bacterial resistance.

Conclusion: As antibiotic resistance amongst bacteria is emerging tremendously, it demands more research. It is still needed to synthesize the novel analogues that would be helpful to cure infections caused by the resistant bacteria. Further these analogues can be tagged with radioisotopes that would be helpful for diagnosis and treatment of infectious diseases.

Keywords: Tetracycline, Structure activity relationship, Pharmacological activity, Analogues, Anti-bacterial.

\section{INTRODUCTION}

Tetracyclines are broad spectrum antibiotics which inhibit the microbial protein synthesis by interfering aminoacyl tRNA and acceptor sites of ribosomes [1].
It exerts its action by binding to 30s ribosomal RNA [2]. It is effective against gram positive and gram negative micro-organisms. Tetracyclines are used widely due to their higher safety profile. It is also used prophylactically against Plasmodium falciparumin 
malaria. It is also used against micro-organisms that are resistant to other antibiotics [3].

\section{Structure Activity Relationship}

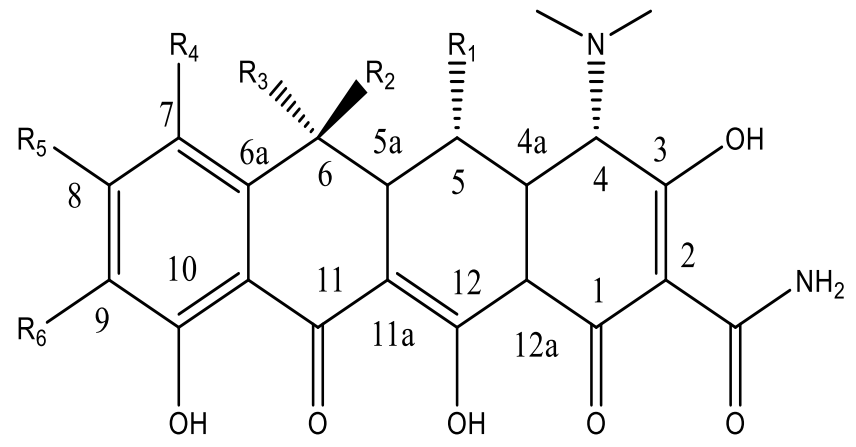

Figure 1. Structure of tetracycline.

Tetracyclines are linearly fused 6 membered, four carbocyclic ring systems as shown in Figure $\mathbf{1 .}$ Among ring $C$ and ring $D$, one must be aromatic. Unsaturation at positions 2- 3 and 11- 12 are essential for activity. Presence of keto-enol system at position 1-3 and 11-12 is necessary for activity. Other important structural features in tetracyclines are amino acyl group at position 2, tertiary amine at position 4, diethyl group at position 5 and position 6 having hydroxyl and methyl group [4].

Amide functional group at position 2 should remain unsubstituted for activity, if substitutions are necessary then one hydrogen can be replaced with alkyl amino methyl group as in rolitetracycline $[5,6]$. Presence of tertiary amines at position 4 is importantto keepketo-enol system of ring Aintact.Position 4 tertiary amine can bear substituents such as hydrazine, hydroxyl or oxime. Epimerization occur at 5a position [7]. Electrophilic substitution can occur at position $7 \& 9$ of ring $D$ with nitro group or halogens; halogens probably used mostly because they are less carcinogenic for host [8].

With respect to discovery and development of tetracyclines, chlortetracycline and oxytetracyclines were firstly originated from Streptomyces aureofaciens and Streptococcus rimosus in 1940s $[9,10]$. This discovery was followed by synthesis of many semi-synthetic tetracyclines such as minocyclines, methacyclins and doxycyclines [11].

Tetracyclines were first discovered by Dr. Benjamin Dugger of Lederle Laboratories in the mid 1940s as the fermentation product of an unusual goldencolored soil bacterium named asStreptomyces aureofacians [12]. These tetracyclins and their analogues have wide range of activity against microbes. Tigecyclinewas found to haveantibacterial activity [13]. Omadacycline was the first intravenous and orally effective 9-aminomethylcycline in clinical development for use against multiple infectiousdiseases including acute bacterial skin and skin structure infections (ABSSSI), communityacquired bacterial pneumonia(CABP), and urinary tract infections (UTI). The comparative in vitro activity of omadacycline was determined against a wide range of Gram-positive clinical isolates, including methicillin-resistant Staphylococcus aureus (MRSA) [14], vancomycin-resistantEnterococcus (VRE), Lancefield groups $A$ and $B$ beta-hemolytic streptococci, penicillin-resistant Streptococcus pneumonia (PRSP), and Haemophilus influenzae $(\mathrm{H}$. influenzae). The omadacycline MIC90s for MRSA, VRE, and beta-hemolytic streptococci [15].

Table 1. Sources, Structures, Pharmacological Activities of Natural Tetracyclines.

\begin{tabular}{|c|c|c|c|}
\hline Sources & Pharmacological Activity & Substitutions \\
\hline Chlotetracyclines[16] & $\begin{array}{c}\text { Antibacterial activity (Primarily } \\
\text { act at 30s / tRNA ribosome). } \\
\text { Used in conjunctivitus in cats, } \\
\text { dogs and horses [47]. }\end{array}$ & $\begin{array}{c}\mathrm{Cl} \text { group at } \\
\text { position } 7\end{array}$ \\
\hline Oxytetracycline [17] & $\begin{array}{c}\text { Primary target is } 30 \mathrm{~s} / \mathrm{tRNA} \\
\text { ribosome and exhibit } \\
\text { antibacterial activity. }\end{array}$ & OH at $5^{\text {th }}$ position \\
\hline
\end{tabular}




Demeclocycline [18]

Table 2. Sources, Structures, Pharmacological Activities of Semisynthetictetracyclines.

\begin{tabular}{|c|c|c|c|}
\hline Sources & Structures & Pharmacological Activity & Substitutions \\
\hline Doxycycline [20] & & $\begin{array}{c}\text { Anticancer (apoptosis and } \\
\text { oxidative Stress mechanism), } \\
\text { veterinary medicine, } \\
\text { Respiratory tract and } \\
\text { intestinal diseases of poultry } \\
\text { [47]. }\end{array}$ & $\begin{array}{l}\mathrm{OH} \text { group at } 5^{\text {th }} \\
\text { position and } \\
\text { deoxylation at } 6^{\text {th }} \\
\text { position }\end{array}$ \\
\hline Lymecycline [21] & & $\begin{array}{l}\text { Antifungal (oxidative } \\
\text { stress) Lonophore and } \\
\text { Chelating Mechanism }\end{array}$ & $\begin{array}{c}\text { Substitution at } 2 \\
\text { position. }\end{array}$ \\
\hline Meclocycline [22] & & $\begin{array}{l}\text { Antifungal (Oxidative } \\
\text { Stress) Lonophore and } \\
\text { Chelating Mechanism }\end{array}$ & $\begin{array}{c}\text { Substitution at } 7 \\
\text { position. }\end{array}$ \\
\hline Methacyclin [23] & & $\begin{array}{l}\text { Antifungal (Oxidative } \\
\text { Stress) Lonophore and } \\
\text { Chelating Mechanism }\end{array}$ & $\begin{array}{c}\text { Methylene group } \\
\text { at } 6^{\text {th }} \text { position \& } \\
\text { OH at } 5^{\text {th }} \\
\text { position }\end{array}$ \\
\hline Minocycline [24] & & $\begin{array}{c}\text { Anticancer (apoptosis and } \\
\text { oxidative Stress mechanism), } \\
\text { veterinary medicine, canine } \\
\text { brucellosis [47]. }\end{array}$ & $\begin{array}{l}\text { Addition of } \\
\text { Dimethylamino } \\
\text { at } 7^{\text {th }} \text { postion \& } \\
\text { removal of } \\
\mathrm{CH} 3 \& \text { OH group } \\
\text { at position } 6^{\text {th }}\end{array}$ \\
\hline
\end{tabular}




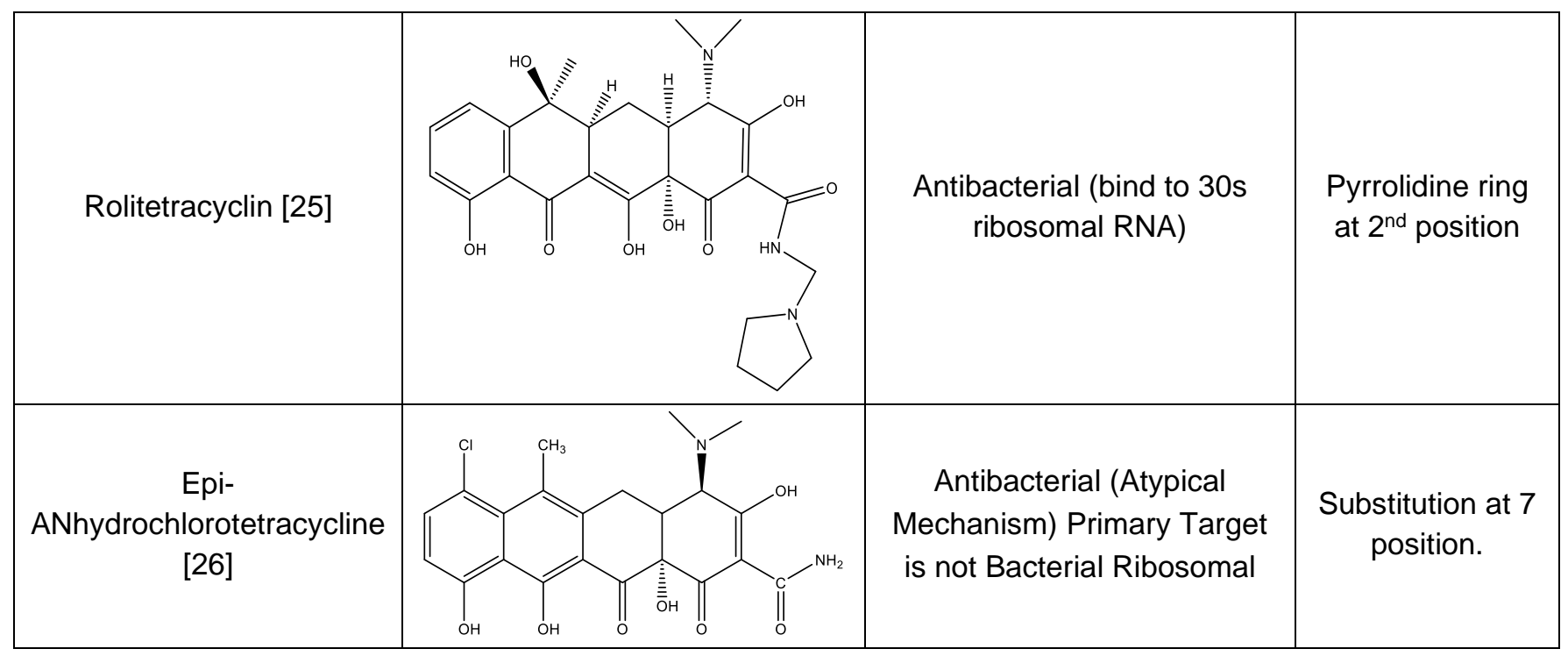

Table 3. Sources, Structures, Pharmacological Activities of Synthetic Tetracyclines.

\begin{tabular}{|c|c|c|c|c|}
\hline Sources & Substitutions \\
\hline Tigecycline [27] & $\begin{array}{c}\text { Substitution at } 9 \\
\text { position. }\end{array}$ & $\begin{array}{c}\text { Sntibacterial (bind to 30s } \\
\text { ribosomal RNA) } \\
\text { \& } 9 \text { position. }\end{array}$ \\
\hline Aminomethylcycline \\
[29]
\end{tabular}




\section{Medicinal Importance of Tetracyclines}

Tetracyclines are broad spectrum antibiotics because its activity is being evaluated against wide array of bacterial infections [32]. Tetracyclines have been used immensely in the prophylaxis and treatment of bacterial infections as they are inexpensive and broad spectrum antimicrobials [33]. Tetracyclines are predominately a low-cost alternative among other antibiotics. Interestingly, certain type of tetracycline has recently been used inprevention of cancer recurrence by inhibiting such enzymes and processes that usually stimulate growth of cancerous cells $[34,6]$. These drugs may show potential for long-term management of some types of cancers [11,35].

\section{Radioprotective Activity}

Kwanghee and coworkers in 2009 conducted a research to recognize medicinal agents that shield body tissues from detrimental effects of radiation therapy. They tested radioprotective activity of tetracyclines and fluoroquinolones in murine lymphocyte rat model which were subjected to total body irradiation. Results manifested that tetracyclines and fluoroquinolones exhibited marked radioprotective activity owing to their planar ring structure. Tetracyclines also averted injurious affects of radiations on human lymphoid cells by preventing DNA strand breakdown. These findings proved that tetracyclines have tremendous potential in reducing radiotherapy damage on normal tissues [36].

\section{Tumor Detection}

Radio isotopes of tetracyclines has been developed and used in localized tumor detection. Tetracycline radioisotope $99 \mathrm{mTc}$ has been successfully employed in external scanning of tumor lesions in rabbits, mice, rats and humans [37].

\section{Anticancer Activity}

Leezenberg and Wesseling in 1979 carried out a retrospective research on 218 cancer patients. These patients were stricken by nasopharyngeal cancer. This study was aimed to evaluate effects of tetracyclines therapy on life span of patients. Results revealed that patients who received tetracyclines not only lived longer but tetracyclines also improved the detrimental effects of methotrexate. It is believed tetracyclines exert this action owing to inhibition of mitochondrial protein synthesis [38].

A study revealed that tetracyclines regulated gene delivery system along with radiation therapy employed in prostate cancerous rat model, developed tumor immunity in cancerous rats and augmented immune response [39].

\section{Prevention of Corneal Ulceration}

Tetracyclines are used as prophylactic treatment for corneal ulceration after severe optical damage. They exert their action by inhibiting protein degradation through its suppressive action on neutrophil collagenase, alpha 1 antitrypsin degradation and through its anti-oxidant activity [40].

\section{Antimicrobial Activity}

Analogues of tetracyclines also show promising antimicrobial activity. 9- substituted analogues of tetracyclines were synthesized by reaction of organotin reagent with salt of C-9 diazonium tetrafluoroborate tetracyclines. These analogues show significant activity against other antibiotic resistant infections [41].

Tetracycline is used in variety of bacterial infections of different body organs such as respiratory pathway, urinary pathway, intestine, reproductive organs, lymph nodes, and skin etc [42]. Many sexually transmitted diseases (STDs) including syphilis, gonorrhea, or chlamydia and also acute acne are treated by these analogues [43].

A wide range of gram positive and gram negitive bacteria e.g. Brucella, Coxiella Burnetii, Rickettsiae rickettsii, Chlamydia trachomatis, Mycoplasma pneumoniae, Chlamydiae species, Helicobacter pylori etc are treated by tetracyclines [44].

\section{Treatment for Acne}

The growth suppression of an anaerobic organism, Cutibacterium acnes, demonstrated by the tetracyclines makes this class of drug important for the treatment of moderate and severe acne. Moreover, the anti-inflammatory effect of tetracyclines is an added advantage for the acne lesions $[43,45,46]$.

\section{Veterinary Use}

Several analogues of tetracyclines including minocycline, methacycline and doxycycline were considered harmful for veterinary use. It was found out that minocycline and doxycycline were rather effective in treatment of animal diseases. These tetracyclines have high lipid solubility that explain its better pharmacokinetic profile that is improved absorption and distribution which may results in efficient antimicrobial activity. Doxycycline excretes 
through intestine; it is useful in renal impairment situations.Doxycycline is used in intestinal and respiratory tract infections in poultry. Minocycline is used in combination with streptomycin in treatment of canine brucellosis [47].

\section{Miscellaneous Uses}

Tetracyclines are useful in treatment of number of diseases such as relapsing fever, syphilis, pneumonia, throat irritation; bacterial urinary tract infection, anthrax, Rocky mountain spotted fever, sinus irritation and congestion, chronic slow progressing ulcerative granulomatous disease [48]. The infections induced by direct contact with the infected animals and adulterated edibles are also treated with antibiotics. Tetracycline can be served as a substitute for penicillin or other antibiotics in cases of severe infections like Anthrax, Listeria, Clostridium, Actinomyces, and others [49]. Tetracyclines are used in treatment of bones and also used for calcification of cartilage $[12,50]$.

\section{Precautions}

The intake of milk, dairy products that contain calcium, iron, antacids, or aluminum salts should be avoided at least 2 hours before or 6 hours after using antacids when using this therapy [51]. Dose of tetracyclines should be taken with water and one hour before or two hours after meals [52, 53].

\section{CONCLUSION}

Tetracyclines belong to a class of broad spectrum antibiotics. Worldwide, they are recommended to cure various gram negative and gram positive bacterial infections. They exert their action by reversibly binding to $30 \mathrm{~S}$ subunit of bacterial ribosome.Tetracyclines analogues are commonly used because of their availability and cost effectiveness especially in developing countries. Thestructure-activity-relationship (SAR) studies of tetracyclines shows the selective bioactivity and strength to the biological targets which makes this class of medicinal compounds able to label with radioisotopes and providing outstanding results in detection and treatment of localized tumors. Furthermore, advanced methods of therapy has been introduced against infectious lesions includes radiotherapy by using the radioisotopes of tetracyclines. In time to come, more radiolabeled tetracyclines analogues can be derivatized for diagnosis and treatment of infectious diseases.

\section{REFERENCES}

1. Wilson DN. Ribosome-targeting antibiotics and mechanisms of bacterial resistance. Nat Rev Microbiol. 2014; 12(1): 35-48.

2. Ferretti JL, Frost HM, Gasser JA, High WB, Jee WSS, Jerome $\mathrm{C}$,et al. Perspectives on osteoporosis research: its focus and some insights from a new paradigm. Calcif Tissue Int. 1995; 57(6): 399-404.

3. Falkow S. Infectious multiple drug resistance. Infect multiple drug resist. 1975.

4. Fuoco D. Classification framework and chemical biology of tetracycline-structure-based drugs. Antibiotics. 2012;1(1).

5. Hinrichs W, Kisker C, Duvel M, Muller A, Tovar K, Hillen W,et al. Structure of the Tet repressortetracycline complex and regulation of antibiotic resistance. Science. 1994; 264(5157): 418-20.

6. Chopra I, Roberts M. Tetracycline antibiotics: mode of action, applications, molecular biology, and epidemiology of bacterial resistance. Microbiol Mol Biol Rev. 2001; 65(2): 232-60.

7. Yalçin I, Ören I, Şener E, Akin A, Ucarturk N. The synthesis and the structure-activity relationships of some substituted benzoxazoles, oxazolo (4, 5-b) pyridines, benzothiazoles and benzimidazoles as antimicrobial agents. Eur J Med Chem. 1992; 27(4): 401-6.

8. Unger B, Klock G, Hillen W, Wells RD. Nucleotide sequence of the repressor gene of the RA1 tetracycline resistance determinant: structural and functional comparison with three related Tet repressor genes. Nucleic Acids Res. 1984; 12(20): 7693-703.

9. Borghi AA, Palma MS. Tetracycline: production, waste treatment and environmental impact assessment. Brazilian J Pharm Sci. 2014; 50(1): 25-40.

10. Finland $M$. Twenty-fifth anniversary of the discovery of Aureomycin: The place of the tetracyclines in antimicrobial therapy. Clin Pharmacol Ther. 1974;15(1):3-8.

11. Zhou Y, Gregor VE, Ayida BK, Winters GC, Sun Z, Murphy D,et al. Synthesis and SAR of 3, 5diamino-piperidine derivatives: novel antibacterial translation inhibitors as aminoglycoside mimetics. Bioorg Med Chem Lett. 2007;17(5): 1206-10.

12. Frost HM. Measurement of human bone formation by means of tetracycline labelling. Can J Biochem Physiol. 1963;41(1):31-42. 
13. Olson MW, Ruzin A, Feyfant E, Rush TS, O'Connell J, Bradford PA. Functional, biophysical, and structural bases for antibacterial activity of tigecycline. Antimicrob Agents Chemother. 2006; 50(6):2156-66.

14. Schmitz FJ, Krey A, Sadurski R, Verhoef J, Milatovic D, Fluit AC. Resistance to tetracycline and distribution of tetracycline resistance genes in European Staphylococcus aureus isolates. J Antimicrob Chemother. 2001;47(2):239-40.

15. Macone AB, Caruso BK, Leahy RG, Donatelli J, Weir S, Draper MP,et al. In vitro and in vivo antibacterial activities of omadacycline, a novel aminomethylcycline. J Antimicrob Chemother. 2014;58(2):1127-35.

16. Zhitie j, Shuqian Z, Chin Pharm Affairs 2009;11 http://en.cnki.com.cn/Article_en/ CJFD TotalZGYS200911024.htm.

17. Armstrong WW. Oxytetracycline Compositions.Google Patents.1977. https://patents.google.com/patent/US4018889A/en

18. Cherrill DA, Stote RM, Birge JR, Singer I. Demeclocycline treatment in the syndrome of inappropriate antidiuretic hormone secretion. Annals of internal medicine. Ann Intern Med. 1975; 83(5): 654-56.

19. Arcamone F. Doxorubicin: anticancer antibiotics. New York :Elsevier; 2012.

20. Takafuji ET, Kirkpatrick JW, Miller RN, Karwacki JJ, Kelley PW, Gray MR,et al. An efficacy trial of doxycycline chemoprophylaxis against leptospirosis.N Engl J Med. 1984;310(8): 497-500.

21. Cunliffe WJ, Meynadier J, Alirezai M, George SA, Coutts I, Roseeuw DI,et al. Is combined oral and topical therapy better than oral therapy alone in patients with moderate to moderately severe acne vulgaris? A comparison of the efficacy and safety of lymecycline plus adapalene gel $0.1 \%$, versus lymecycline plus gel vehicle. J Am Acad Dermatol. 2003; 49(3): S218-26.

22. Knutson DD, Swinyer LJ, Smoot WH. Meclocycline sulfosalicylate. Topical antibiotic agent for the treatment of acne vulgaris. Cutis. 1981; 27(2): 2034.

23. Kunin CM. Comparative serum binding, distribution and excretion of tetracycline and a new analogue, methacycline. Exp Biol Med. 1962;110(2):311-5.

24. Goulden V, Glass D, Cunliffe WJ. Safety of long-term high-dose minocycline in the treatment of acne. Br J Dermatol. 1996;134(4): 693-5.
25. Karlíček R, Solich P. Flow-injection spectrophotometric determination of tetracycline antibiotics. Anal Chim Acta. 1994; 285(1-2): 9-12.

26. Loftin KA, Adams CD, Meyer MT, Surampalli R. Effects of ionic strength, temperature, and $\mathrm{pH}$ on degradation of selected antibiotics. J Environ Qual. 2008; 37(2): 378-86.

27. Babinchak T, Grosse EE, Dartois N, Rose GM. The efficacy and safety of tigecycline for the treatment of complicated intra-abdominal infections: analysis of pooled clinical trial data. Clin Infect Dis. 2005;41(5): S354-67.

28. Townsend ML, Pound MW, Drew RH. Tigecycline: a new glycylcycline antimicrobial. Int $\mathrm{J}$ Clin Pract. 2006; 60(12): 1662-72.

29. Draper MP, Weir S, Macone A, Donatelli J, Trieber CA, Tanaka SK, et al. Mechanism of action of the novel aminomethylcycline antibiotic omadacycline. Antimicrob Agents Chemother. 2014; 58(3): 127983.

30. Xiao XY, Hunt DK, Zhou J, Clark RB, Dunwoody $\mathrm{N}$, Fyfe $\mathrm{C}$,et al. Fluorocyclines. 1. 7-fluoro-9pyrrolidinoacetamido-6-demethyl-6-

deoxytetracycline: a potent, broad spectrum antibacterial agent. J Med Chem. 2012; 55(2): 597-605.

31. Villano S, Steenbergen J, Loh E. Omadacycline: development of a novel aminomethylcycline antibiotic for treating drug-resistant bacterial infections. Future Microbiol. 2016;11(11): 1421-34.

32. Softa M, Percoco G, Lati E, Bony P. Birch Sap (Betula alba) and Chaga Mushroom (Inonotus obliquus) Extracts Show Anti-Oxidant, AntiInflammatory and DNA Protection/Repair Activity In Vitro. J Cosmetics Dermatol Sci Appl. 2019; 9(2): 188-205.

33. Grimes DA, Schulz KF, Cates Jr W. Prophylactic antibiotics for curettage abortion. Am J Obstet Gynecol. 1984;150(6): 689-94.

34. Golub LM, Wolff M, Lee HM, McNamara TF, Ramamurthy NS, Zambon J,et al. Further evidence that tetracyclines inhibit collagenase activity in human crevicular fluid and from other mammalian sources. J Periodontal Res. 1985; 20(1):12-23.

35. Seymour RA, Heasman PA. Tetracyclines in the management of periodontal diseases: A review. $\mathrm{J}$ Clin Periodontol. 1995; 22(1): 22-35.

36. Kim K, Pollard JM, Norris AJ, McDonald JT, Sun $\mathrm{Y}$, Micewicz E,et al. High-throughput screening identifies two classes of antibiotics as radioprotectors: tetracyclines and fluoroquinolones.Clin Cancer Res. 2009;15(23): 7238-45. 
37. Holman BL, Kaplan WD, Dewanjee MK, Fliegel CP, Davis MA, Skarin AT,et al. Tumor detection and localization with 99mTc-tetracycline. Radiology. 1974; 112(1): 147-54.

38. Leezenberg JA, Wesseling $\mathrm{H}$, Kroon AM. Possible cytostatic action of tetracyclines in the treatment of tumors of the nasopharynx and larynx.Eur $\mathrm{J}$ Clin Pharmacol. 1979; 16(4): 237-41.

39. Tsai $\mathrm{CH}$, Hong JH, Hsieh KF, Hsiao HW, Chuang WL, Lee CC,et al. Tetracycline-regulated intratumoral expression of interleukin-3 enhances the efficacy of radiation therapy for murine prostate cancer.Cancer Gene Ther. 2006; 13(12): 1082-92.

40. Ralph RA. Tetracyclines and the treatment of corneal stromal ulceration: a review. Cornea. 2000; 19(3): 274-7.

41. Koza DJ, Nsiah YA. Synthesis and biological evaluation of 9-substituted tetracycline derivatives.Bioorg Med Chem Lett. 2002; 12(16): 2163-5.

42. Teixeira L, Ferreira Á, Ashburner M. The bacterial symbiont Wolbachia induces resistance to RNA viral infections in Drosophila melanogaster. PLoS biol. 2008; 6(12).

43. McCormack WM, Almeida PC, Bailey PE, Grady EM, LeeYH. Sexual activity and vaginal colonization with genital mycoplasmas. Jama. 1972; 221(12): 1375-7.

44. Biedenbach DJ, Beach ML, Jones RN. In vitro antimicrobial activity of GAR-936 tested against antibiotic-resistant gram-positive blood stream infection isolates and strains producing extendedspectrum $\beta$-lactamases. Diagn Microbiol Infect Dis. 2001; 40(4): 173-7.

45. Speer BS, Shoemaker NB, Salyers AA. Bacterial resistance to tetracycline: mechanisms, transfer, and clinical significance. Clin Microbiol Rev. 1992;5(4): 387-99.

46. Rudy SJ. Overview of the evaluation and management of acne vulgaris. J Pediatr Nurs. 2003; 29(4): 287-96.

47. Aronson AL. Pharmacotherapeutics of the newer tetracyclines. J Am Vet Med Assoc. 1980; 176(10): 1061-8.

48. Pullen H, Wright N, Murdoch JM. Hypersensitivity reactions to antibacterial drugs in infections mononucleosis Lancet. 1967; 290(7527): 1176-8.

49. Rieckmann $\mathrm{KH}$, Powell RD, McNamara JV, Willerson JrD, Kass L, Frischer $\mathrm{H}$, et al. Effects of tetracycline against chloroquine-resistant and chloroquine-sensitive Plasmodium falciparum. Am J Trop Med Hyg. 1971; 20(6): 811-5.

50. Cohlan SQ, Bevelander G, Tiamsic T. Growth inhibition of prematures receiving tetracycline: $A$ clinical and laboratory investigation of tetracyclineinduced bone fluorescence. Am J Dis Child. 1963; 105(5): 453-61.

51. Sasidharan S, Prema B, Latha LY. Antimicrobial drug resistance of Staphylococcus aureus in dairy products. Asian. Pac J Trop Biomed. 2011;1(2): 130-2.

52. Welling PG, Koch PA, Lau CC, Craig WA. Bioavailability of tetracycline and doxycycline in fasted and nonfasted subjects. Antimicrob Agents Chemother. 1977;11(3): 462-9.

53. Sánchez AR, Rogers III RS, Sheridan PJ. Tetracycline and other tetracycline-derivative staining of the teeth and oral cavity. Int J Dermatol. 2004; 43(10):709-15. 